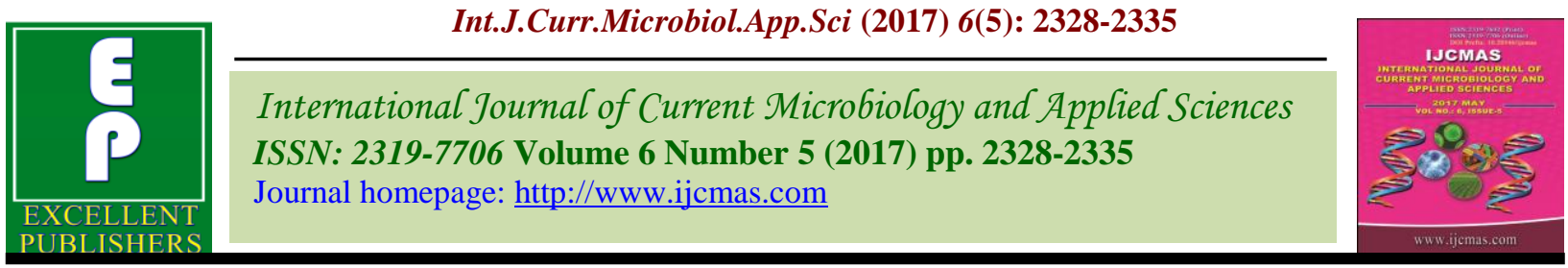

Original Research Article https://doi.org/10.20546/ijcmas.2017.605.260

\title{
Automated and Non-Automated Fertigation Systems Inside the Polyhouse- A Comparative Evaluation
}

\author{
Anjaly C. Sunny* and V.M. Abdul Hakkim \\ Department of Land and Water Resources and Conservation Engineering (LWRCE), KCAET \\ (Kerala Agricultural University), Tavanur (P.O.), Malappuram (Dt.), Kerala - 679573, India \\ *Corresponding author
}

\section{A B S T R A C T}

\section{Keywords}

Biometric observations, Cucumber, FIP, Fertigation, Polyhouse, Yield parameters.

\section{Article Info}

Accepted:

25 April 2017

Available Online: 10 May 2017
Automated fertigation system is a highly advanced system for water and fertilizer administration in irrigated agriculture. It promises the application of water in right quantity along with right fertilizer at right time, thereby reducing fertilizer loss and labour resulting in saving of money with the help of an automated mechanism. The present study was undertaken to evaluate the performance of a timer based automated fertigation system with an FIP. Field evaluation of the developed automated fertigation system was carried out by growing salad cucumber variety 'Saniya' in grow bags inside a poly house located at Agricultural Research Station, Anakkayam. Comparative evaluation was carried out between biometric observations and yield parameters of the two sets of crops, one fertigated automatically with the developed system the other one fertigated using venturi injector. Data collected was subjected to statistical scrutiny viz., ANOVA (Analysis of Variance) and Student-t test. The main crop growth parameters like height of the plant, days to first flowering, days to 50 percentage flowering, days to initial budding, days to first harvest and leaf area index were observed. Yield parameters viz. size of the fruit, number of fruits harvested per plant and average yield were recorded during the study. Values of all these parameters were found to be better for the crops grown inside the polyhouse with automated fertigation compared to the other.

\section{Introduction}

The adoption of fertigation by farmers largely depends on the benefits derived from it and fertigation is in its introductory stage in Kerala. Its success in terms of improved production depends upon how efficiently plants take up the nutrients. Proper scheduling and intervals are also needed to provide nutrients at a time when plants require them. The adoption of fertigation worldwide has shown favourable results in terms of fertilizer use efficiencies and quality of produce besides the environmental advantages. The choice of selecting various water soluble fertilizers are enormous and therefore, selection of chemicals should be based on the property of avoiding corrosion, softening of plastic pipe network, safety in field use and solubility in water. 
Automated fertigation system is a highly advanced system of drip automation for water and fertilizer administration in agriculture. It promises the application of water in right quantity with right fertilizer at right time, without manual endeavours and labour. Thus, labour cost could be reduced with the help of an automated mechanism. Using an automated fertigation system can help producers to make correct choices that can essentially affect water and fertilizer utilization and can decrease fertilizer lose. Some automated systems are capable of integrating irrigation scheduling with nutrient dosing activities while other systems only manage the nutrient dosing equipment.

This paper does the comparative evaluation of automated and non-automated fertigation systems inside the poly house.

\section{Materials and Methods}

\section{Experimental setup}

\section{Polyhouse}

Poly houses are basically naturally ventilated climate control structures mainly used for applications like growing vegetables, floriculture, planting material acclimatization etc. Poly house used for this experiment was made using GI class B pipe poles. The roofing is provided with a transparent UV (Ultra Violet) stabilized low density polyethylene sheet of 200 micron thickness, which creates a micro climate inside the poly house by regulating relative humidity and temperature, as it partially cuts the UV rays. The specifications of the poly house used for the study are as given in Table 1 .

\section{Crop and variety}

Salad Cucumber (Cucumis sativus) variety: Saniya was used for the experiment. It is a high yielding variety which grows vigorously and mostly bears female flowers. The fruit skin is glossy green with few spines and it tastes crispy and sweet, making it suitable for salad or frying and the crop is most suited for poly house cultivation. Seeds were sown in a pro tray containing mixture of vermi compost and coir pith in $1: 1$ ratio to a depth of $0.5 \mathrm{~cm}$. These seedlings were transplanted into grow bags on the seventh day.

\section{Experimental procedure}

Evaluation of the automated fertigation system was carried out by installing the system in a polyhouse of $291.9 \mathrm{~m} 2$. Total 186 plants were planted in the poly house and were automatically fertigated; another 24 plants were planted in the same poly house which was fertigated using venturi injector. The biometric and yield parameters of randomly selected plants, 4 and 7 in number respectively from each plot were noted and were compared with each other to evaluate the efficiency of the system using statistical analysis.

\section{Layout of the experiment}

First set of plants with automated fertigation system were grown inside the poly house in seven rows at spacing of $2 \times 1.5 \mathrm{~m}$ with 24 plants in one row and 27 plants in the other six rows adding to a total number of 186 plants. The next set of plants, fertigated using venturi injector was grown in the same poly house with 24 plants planted in a single row.

All the plants were grown in grow bags of size $24 \times 24 \times 40 \mathrm{~cm}$ with potting mixture which contained soil, coir pith and dried farm yard manure (FYM) in the ratio 2:1:1. Drip irrigation system with an emitter spacing of $1.5 \mathrm{~m}$ was installed in all the plots with arrow drips of 8 lph capacity. 


\section{Automated fertigation system}

The fertigation system was installed inside the polyhouse. The required amount of different fertilizers for the plant is filled in separate fertilizer tanks and the tank is filled with desired quantity of water with the help of push button switch. Fertilizers used were ammonium nitrate $\left(\mathrm{NH}_{4} \mathrm{NO}_{3}\right)$, monoammonium phosphate $\left(\mathrm{NH}_{4} \mathrm{H}_{2} \mathrm{PO}_{4}\right)$ and potassium sulphate $\left(\mathrm{K}_{2} \mathrm{SO}_{4}\right)$. Inside each tank, these fertilizer solutions are mixed thoroughly with the help of a bubbler. After mixing, the solutions are pumped to the mixing tank sequentially according to the preset timings from where it is pumped to the drip system through FIP. Other nutrient fertilizers such as calcium nitrate $\left(\mathrm{Ca} \quad\left(\mathrm{NO}_{3}\right)_{2}\right)$ which were essential for the plant growth were directly fed into the mixing tank in the form of solutions whenever necessary.

\section{Field data collection}

\section{Biometric observations}

Biometric analysis on growth of the plant was done. The main crop growth parameters like height of the plant, days to initial budding, days to first flowering, days to 50 percentages flowering, days to first harvest, Leaf Area Index (LAI) were observed. Biometric observations of 4 randomly selected plants were taken from each plot.

\section{Height of the plant}

Height of the plant was measured from ground level to tip of top most leaf. Readings were recorded for each selected plants from three different treatment plots from the transplanted date at an interval of 18 days.

\section{Number of days to initial budding}

The time taken by the crop to start initial budding stage from date of transplanting was observed. The number of days for each treatment was recorded.

\section{Number of days to first flowering}

The time taken by the crops from initial budding to start initial flowering stage from date of transplanting was observed. The number of days was recorded for each treatment.

\section{Number of days to $50 \%$ flowering}

The time by which, $50 \%$ of the plants got its flowers from date of transplanting was observed. The number of days for each treatment was recorded.

\section{Number of days to first bearing}

The time by which first fruit was seen from date of transplanting was observed. The number of days for each treatment was recorded.

\section{Number of days to first harvest}

The number of days taken by the crops to reach final fruiting stage for the first harvest was recorded for each treatment.

\section{Leaf area index}

The average length and width of five leaves of the selected plants were taken from the date of transplanting at an interval of 18 days and the mean leaf area (LAm) and in turn the leaf area index (LAI) was found out by the method of estimation suggested by Blanco and Folegatti (2003).

Where, L, W are the average of length and width of the leaves of the selected plant, $\mathrm{N}$ the number of leaves in that plant and A the area occupied by the plant. 


\section{Yield parameters}

Yield parameters like size of the fruit, number of fruits harvested per plant and yield of seven plants were recorded during the study.

\section{Number of fruits/plant}

Seven plants were selected randomly from each plot. The total number of fruits per plant was recorded at each harvest and the added total number at the end of the crop was calculated as the yield of randomly selected plants.

\section{Size of the fruit}

Seven plants were selected randomly from each plot. The length and equatorial circumference of each fruit obtained was measured and average for each plant was calculated.

\section{Yield (t/ha)}

Harvesting of the crop was done in each plot after attaining maturity. Weight of harvested fruits was taken and the yield was worked out in $\mathrm{t} / \mathrm{ha}$.

\section{Statistical analysis}

The data collected was subjected to statistical scrutiny viz., ANOVA (Analysis of Variance) and Student-t test and executed using the software SYSTAT and MS Excel. CRD design was used for the analysis. Wherever the results were significant, critical differences were worked out at probability level $\mathrm{p}<0.05$. The non-significant differences were denoted as NS. With respect to Student $t$ test, if the calculated value exceeds the table value, then the treatment is significantly different at that level of probability based on the hypothesis tested. In the present study it was considered a significant difference at $\mathrm{p}=$ 0.05 , and this means that if the null hypothesis were correct (i.e. the treatments do not differ) then " $t$ " value has to be greater as this, on less than $5 \%$ of occasions. This means that, the treatments do differ from one another, but we still have nearly a 5\% chance of being wrong in reaching this conclusion.

\section{Results and Discussion}

Comparative evaluation was carried out between biometric observations and yield parameters of the two sets of crop grown inside the polyhouse, one fertigated automatically with the developed system and the other one fertigated using venturi injector at various stages of plant growth. It is indicated as $\mathrm{T} 1$ and $\mathrm{T} 2$ respectively. The readings were taken once in a week from both the plots.

\section{Biometric observations}

\section{Height of the plant}

Drip fertigation can enable the application of soluble fertilizers and other chemicals along with irrigation water in the vicinity of the root zone (Patel and Rajput, 2011); (Narda and Chawla, 2002). The application of water and nutrients in small doses at frequent intervals in the crop root zone ensures their optimum utilization and higher growth (Jayakumar et al., 2014). The results in Table 2 shows that at the final stages, plant height was significant between the individual treatments i.e., T1 outperformed T2. This indicated the superiority of the automated drip fertigation $\mathrm{T} 1$ than the other. It registered the maximum plant height of $273.0 \mathrm{~cm}$ at the 4th observation, followed by T2 with $242.8 \mathrm{~cm}$. The concentration and availability of various nutrients in the soil for plant uptake depends on the soil solution phase which is mainly determined by soil moisture availability.

\section{Flowering parameters}

Earliest flowering was obtained in the treatment $\mathrm{T} 1$ (21 days), whereas in the 
treatment T2, it was late by 3 days as shown in Table 3. The optimum levels of nutrient status in the media aided early flowering and the increase in number of pistillate flowers might be due to the vigorous vine growth and more number of branches resulting in increased metabolic activity in cucumber (Bishop et al., 1969) Similar is the case in 50 per cent flowering, first fruit and first harvest for $\mathrm{T} 1$ and which was followed by $\mathrm{T} 2$.

\section{Leaf Area Index}

The results in Table 4 indicate that at all the stages; the values of $\mathrm{T} 1$ were numerically higher, when compared to T2. This indicated that uniform application of fertilizer through drip fertigation could give maximum leaf growth for cucumber. The vegetative growth of the plant is directly related to the nitrogen applied (Klein et al., 1989). Moreover according to studies conducted by Baruah and Mohan (1991), potassium application is important in leaf growth and development. Nitrogen, phosphorus and potassium are three necessary nutrients which affect the plant growth and thus the uniform and frequent application of fertilizer through developed automated drip fertigation system might have result in the better leaf area index.

\section{Yield parameters}

\section{Number of fruits per plant}

The result in Table 5 shows that T1 recorded the higher number of fruits per plant than $\mathrm{T} 2$ statistically significant. It registered the maximum number of 29.12 fruits per plant and this was followed by T2 with 10.50 fruits. The increase in number of fruits of $\mathrm{T} 1 \mathrm{might}$ be due to the increased vegetative growth of the plants grown under the developed system leading to enhanced nutrient uptake and better water utilization which results in increased rate of photosynthesis and translocation of nutrients into the reproductive part or the produce compared to the conventional method of fertilizer application. The present findings are in accordance with the results of Sharma et al., (2011). According to Ramnivas et al., (2012), interaction of irrigation and fertigation might have resulted to maximum fruit weight.

\section{Size of the fruit}

The results in Table 6 show that the automated drip fertigation system in polyhouse T1 recorded the higher fruit weight than the other two treatments. It registered the maximum fruit weight of $246.4 \mathrm{~g}$ and this was followed by T2 with $212.9 \mathrm{~g}$. As shown in Table 7, T1 registered the maximum fruit length of $21.35 \mathrm{~cm}$ and it was followed by $\mathrm{T} 2$ with $20.70 \mathrm{~cm}$. The increase in length of the fruit might be due to regular water and nutrient supply through drip fertigation, crop plants can complete all metabolic process at appropriate time. The adequate moisture and moisture supply also helps in keeping various enzyme systems active. Therefore, quality of the produce is better in drip fertigated crops as compared to control.

The result in Table 8 shows that the T1 recorded the higher equatorial circumference than the other two treatments. It registered the maximum equatorial circumference of 16.25 $\mathrm{cm}$ and this was followed by T2 with 12.75 $\mathrm{cm}$. This is because of the increase in crop growth due to the interaction effect between irrigation and fertigation levels. 100 percentage applications of the scheduled nutrients to the root zone had also contributed to the fruit diameter (Ramnivas et al., 2012). These findings are in agreement with the report of Singh and Singh (2005) that the trickle irrigation with $100 \%$ recommended nitrogen fertilizer gave the maximum fruit circumference, fruit length and fruit weight in papaya. 
Table.1 Specification of poly house

\begin{tabular}{ll}
\hline Particulars & Specifications \\
\hline Centre height & $6.5 \mathrm{~m}$ \\
Side height & $4 \mathrm{~m}$ \\
Area inside & $291.9 \mathrm{~m}^{2}$ \\
GI pipes & Class B of 2 inch diameter \\
Roofing & 200 micron thickness UV stabilized LDPE \\
Side net & 40 mesh nylon insect proof net \\
\hline
\end{tabular}

Table.2 Influence of different treatments on plant height of cucumber at various stages of growth

\begin{tabular}{lllll}
\hline Plant height $(\mathbf{c m})$ & \multicolumn{4}{l}{ Observations } \\
\hline & $\mathbf{1}^{\text {st }}$ & $\mathbf{2}^{\text {nd }}$ & $\mathbf{3}^{\text {rd }}$ & $\mathbf{4}^{\text {th }}$ \\
\hline $\mathrm{T}_{1}$ & 18.5 & 77.8 & 159.3 & 273.0 \\
$\mathrm{~T}_{2}$ & 22.0 & 62.0 & 142.8 & 242.8 \\
\hline $\mathrm{T}_{1} \mathrm{Vs} \mathrm{T}_{2}$ (t value) & $\mathrm{NS}$ & $\mathrm{NS}$ & $4.34^{* *}$ & $6.58^{* *}$ \\
\hline
\end{tabular}

** Significant at $\mathrm{p}<0.05$; NS - Non significant

Table.3 Date of occurrence of differing flowering parameters

\begin{tabular}{lll}
\hline Events & T1 & T2 \\
\hline First flower bud & $27-12-15$ & $28-12-15$ \\
First flowering & $04-01-16$ & $07-01-16$ \\
50\% flowering & $07-01-16$ & $09-01-16$ \\
First fruit & $06-01-16$ & $09-01-16$ \\
First harvest & $15-01-16$ & $21-01-16$ \\
\hline
\end{tabular}

Table.4 Influence of different treatments on LAI of cucumber plant at three stages of growth

\begin{tabular}{llll}
\hline LAI & $\mathbf{2}^{\text {nd }}$ & $\mathbf{3}^{\text {rd }}$ & $\mathbf{4}^{\text {th }}$ \\
\hline $\mathrm{T}_{1}$ & 15.80 & 36.90 & 58.6 \\
$\mathrm{~T}_{2}$ & 9.01 & 17.19 & 36.9 \\
\hline $\mathrm{T}_{1} \mathrm{Vs} \mathrm{T}_{2}$ (t value) & $7.89^{* *}$ & $2.53^{* *}$ & $4.229^{* *}$ \\
\hline
\end{tabular}

** Significant at $\mathrm{p}<0.05 ; \mathrm{NS}$ - Non significant

Table.5 Influence of different treatments on number of fruits per plant of the cucumber

\begin{tabular}{ll}
\hline Treatments & No. of fruits/plants \\
\hline $\mathbf{T}_{\mathbf{1}}$ & $29.12^{\mathrm{a}}$ \\
$\mathbf{T}_{\mathbf{2}}$ & $10.50^{\mathrm{b}}$ \\
\hline SEd & 2.266 \\
$\mathrm{CD}(\mathrm{P}=0.05)$ & 5.388 \\
\hline
\end{tabular}


Table.6 Influence of different treatments on weight of the cucumber fruit

\begin{tabular}{ll}
\hline Treatments & Average weight of the single fruit $(\mathbf{g})$ \\
\hline $\mathrm{T}_{1}$ & $246.4^{\mathrm{a}}$ \\
$\mathrm{T}_{2}$ & $212.9^{\mathrm{b}}$ \\
\hline $\mathrm{SEd}$ & 13.063 \\
$\mathrm{CD}(\mathrm{P}=0.05)$ & 27.44 \\
\hline
\end{tabular}

Table.7 Influence of different treatments on length of the cucumber fruit

\begin{tabular}{ll}
\hline Treatments & Length $(\mathbf{c m})$ \\
\hline $\mathrm{T}_{1}$ & $21.35^{\mathrm{a}}$ \\
$\mathrm{T}_{2}$ & $20.70^{\mathrm{a}}$ \\
\hline $\mathrm{SEd}$ & 0.77 \\
$\mathrm{CD}(\mathrm{P}=0.05)$ & 1.62 \\
\hline
\end{tabular}

Table.8 Influence of different treatments on equatorial circumference of the cucumber

\begin{tabular}{ll}
\hline Treatments & Equatorial circumference $(\mathbf{c m})$ \\
\hline $\mathrm{T}_{1}$ & 16.25 \\
$\mathrm{~T}_{2}$ & 12.75 \\
\hline $\mathrm{CD}(\mathrm{P}=0.05)$ & $\mathrm{NS}$ \\
\hline
\end{tabular}

Table.9 Influence of different treatments on total yield of the cucumber fruit

\begin{tabular}{ll}
\hline Treatments & Total Yield (t/ha) \\
\hline $\mathrm{T}_{1}$ & $23.86^{\mathrm{a}}$ \\
$\mathrm{T}_{2}$ & $7.71^{\mathrm{b}}$ \\
\hline $\mathrm{SEd}$ & 1.16 \\
$\mathrm{CD}(\mathrm{P}=0.05)$ & 2.44 \\
\hline
\end{tabular}

\section{Total yield}

The results in Table 9 show that the automated drip fertigation system in polyhouse $\mathrm{T} 1$ recorded the higher fruit yield of $23.86 \mathrm{t}$ ha-1 and this was statistically significant over $\mathrm{T} 2$ with $7.71 \mathrm{t}$ ha-1. This might be due to the combined effect of cultivars, wider spacing, polyhouse cultivation and timely and uniformly availability of all the nutrients through the developed automated fertigation system. The present results are in agreement with the findings of Arora et al.,(2006) in greenhouse grown tomato; Ban et al., (2006) in melons.
Automated drip fertigation of cucumber adequately sustain favorable vegetative and reproductive growth as compare to conventional method of fertilizer application. Crop growth parameters like height of the plants, days to initial budding, days to $50 \%$ flowering, days to first fruit, days to first harvest and leaf area index and the yield parameters such as number of fruits per plant, weight of the fruit, length of the fruit, equatorial circumference of the fruit and total yield in $t / h a$ were observed for the 2 treatments, T1, T2 viz. crop grown inside the polyhouse and fertigated using the developed system, crop grown inside the polyhouse 
fertigated using ventury injector. It is evident from the recorded data that the $\mathrm{T} 1$ outperformed $\mathrm{T} 2$ in case of all the parameters.

It can be concluded from the present study it can be inferred that the automated fertigation system installed inside the polyhouse $\mathrm{T} 1$ can be considered as the best treatment as it gave the maximum value of yield parameters and biometric observations. Thus it can be concluded that the developed system for automatic fertigation ensured better yield for cucumber variety 'Saniya' grown inside the polyhouse.

\section{References}

Arora, S.K., Bhatia, A.K., Singh, V.P. and Yadav, S.P.S. 2006. Performance of indeterminate tomato hybrids under greenhouse conditions of north Indian plains. Haryana J. Hortic. Sci., 35(3\&4): 292-294.

Ban, D., Goreta, S. and Borosic, J. 2006. Plant spacing and cultivar affect melon growth and yield components. Sci. Hortic., 109: 238-243.

Baruah, P.J. and Mohan, N.K. 1991. Effect of potassium on LAI, phyllochrome and number of leaves of banana. Banana Newsl., 14: 21-22.

Bishop, R.F., Chipmon, E.W. and Mae eachern, C. R. 1969. Effect of nitrogen, phosphorous and potassium on yield and nutrient levels in laminate and petioles of pickling cucumber. Can. J. Soil Sci., 49: 297-404.

Blanco, F.F. and Folegatti, M.V. 2003. A new method for estimating the leaf area index of cucumber and tomato plants. Hortic. Brasileira, 21(4): 666-669.

Jayakumar, M., Surendran, U. and Manickasundaram, P. 2014. Drip fertigation effects on yield, nutrient uptake and soil fertility of Bt Cotton in semi arid tropics. Int. J. Plant Prod., 8(3).

Klein, L., Levin, L., Bar-Yosef, B., Assaf, R. and Berkovitz, A. 1989. Drip nitrogen fertigation of 'Starking Delicious' apple trees. Plant and Soil, 119(2): 305-314.

Narda, N.K. and Chawla, J.K. 2002. A simple nitrate sub-model for trickle fertigated potatoes. Irrig. Drain, 51: 361-371.

Patel, N. and Rajput, T.B.S. 2011. Simulation and modelling of water movement in potato (Solanumtuberosum). The Indian J. Agric. Sci., 81: 25-32.

Ramnivas, Kaushik, R.A., Sarolia, D.K., Pareek, S. and Singh, V. 2012. Effect of irrigation and fertigation scheduling on growth and yield of guava (Psidiumguajava L.) under meadow orcharding. Afr. J. Agric. Res., 7(47): 6350-6356.

Sharma, A., Kaushik, R.A., Sarolia, D.K. and Sharma R.P. 2011. Response of cultivars, plant geometry and methods of fertilizer application on parthenocarpic cucumber (Cucumissativus L.) under zero energy polyhouse condition. Veg. Sci., 38(2): 215-217.

Singh, H.K. and Singh, A.K.P. 2005.Effect of refrigeration on fruit growth and yield of papaya with drip irrigation. Environ. Ecol., 23: 692-695.

\section{How to cite this article:}

Anjaly C. Sunny and Abdul Hakkim. 2017. Automated and Non-Automated Fertigation Systems inside the Polyhouse- A Comparative Evaluation. Int.J.Curr.Microbiol.App.Sci. 6(5): 2328-2335. doi: https://doi.org/10.20546/ijcmas.2017.605.260 